\title{
ANALISIS KINERJA KEUANGAN KOPERASI KELUARGA TRIDINANTI PALEMBANG
}

\author{
Aida Rakhmawati ${ }^{1)}$ Yusro Hakimah $^{2)}$ Hasyunah $^{3)}$ \\ 1. Dosen jurusan Akuntansi, Universitas Tridinanti Palembang Sumatera Selatan \\ 2,3) Dosen jurusan Manajemen, Universitas Tridinanti Palembang Sumatera Selatan \\ 1) rakhmawatiaida@gamil.com
}

\begin{tabular}{l} 
INFORMASI ARTIKEL \\
\hline Submitted: \\
16/11/2021 \\
Revised: \\
$05 / 12 / 2021$ \\
Accepted: \\
25/12/2021 \\
Print-Published: \\
31/12/2021
\end{tabular}

\begin{abstract}
ABSTRAK
Koperasi memerlukan alat guna mengetahui kinerja keuangan koperasi agar manajemen koperasi dapat melaksanakan tugas dan kewajibannya dengan baik sesuai dengan tujuan koperasi pada umumnya. Sebagai pedoman umum dalam mengetahui kinerja keuangan diperlukan laporan keuangan yang diterbitkan oleh koperasi, untuk mengetahui keberhasilan maupun permasalahan yang dialami koperasi dalam pengelolaan keuangannya. Tujuan dari penelitian ini adalah untuk mengetahui dan menganalisis kinerja keuangan Koperasi Keluarga Tridinanti tahun 2015-2020. Jenis data yang digunakan adalah data sekunder dengan teknik pengumpulan data berupa laporan neraca keuangan dan laporan sisa hasil usaha. Hasil penelitian menyimpulkan bahwa kinerja Koperasi Keluarga Tridinanti selama enam tahun terakhir yaitu tahun 2015 sampai tahun 2020 pada umumnya sudah sangat baik
\end{abstract}

Katakunci: kinerja keuangan Koperasi

\begin{abstract}
Cooperatives need tools to determine the financial performance of cooperatives so that cooperative management can carry out their duties and obligations properly in accordance with the objectives of cooperatives in general. As a general guideline in knowing financial performance, it is necessary to have financial reports issued by cooperatives, to find out the success and problems experienced by cooperatives in managing their finances. The purpose of this study was to determine and analyze the financial performance of the Tridinanti Family Cooperative in 2015-2020. The type of data used is secondary data with data collection techniques in the form of financial balance reports and reports of remaining operating results. The results of the study concluded that the performance of the Tridinanti Family Cooperative for the last six years, from 2015 to 2020, was generally very good.
\end{abstract}

Keywords: Cooperative financial performance

\section{PENDAhUluaN}

Koperasi adalah salah satu bentuk usaha berbadan hukum yang berdiri di Indonesia. Menurut Undang-Undang No 25 Tahun 1992 pasal 1 ayat 1 tentang perkoperasian, koperasi Indonesia adalah badan usaha yang beranggotakan orangorang atau badan hukum koperasi dengan melandaskan kegiatannya berdasarkan prinsip koperasi, sekaligus sebagai gerakan ekonomi rakyat yang berdasarkan asas kekeluargaan.
Usaha koperasi adalah usaha yang sesuai dengan demokrasi ekonomi, karena didalam demokrasi ekonomi terdapat unsur-unsur usaha koperasi. Koperasi adalah bentuk kerjasama di bidang ekonomi yang sesuai dengan Pancasila dan UUD 1945. Di dalam UUD 1945 pasal 33 ayat 1 ditegaskan bahwa perekonomian disusun sebagai usaha bersama berdasarkan azas kekeluargaan.

Kinerja keuangan adalah gambaran tentang keberhasilan suatu usaha yaitu berupa hasil yang telah dicapai dengan berbagai aktivitas yang 
telah dilakukan. Kinerja keuangan merupakan suatu analisis untuk menilai sejauh mana suatu perusahaan telah melaksanakan aktivitas sesuai aturanaturan pelaksanaan keuangan (Fahmi, 2012).

Analisis laporan keuangan mencakup pengaplikasian berbagai alat dan teknik analisis pada laporan dan data keuangan untuk memperoleh ukuran dan hubungan yang berarti dan berguna dalam proses pengambilan keputusan Dengan demikian tujuan analisis laporan keuangan adalah mengkonversikan data menjadi informasi. Ada beberapa tujuan yang ingin dicapai dalam analisis laporan keuangan misalnya sebagai alat forecasting mengenai kondisi dan kinerja keuangan

Untuk mengetahui apakah usaha yang dilakukan koperasi mengalami perkembangan, diadakan analisa mengenai faktor-faktor yang mendukung pencapaian usaha. Salah satu faktor tersebut dapat dilihat dari interpretasi atau analisa laporan keuangannya, yang terdiri dari analisa rasio likuiditas, solvabilitas dan rentabilitas. Rasio likuiditas menggambarkan tingkat kemampuan koperasi untuk dapat memenuhi kewajiban finansialnya

Koperasi Keluarga Tridinanti Palembang melakukan penghimpunan dana dari anggota dalam bentuk simpanan pokok, simpanan wajib, dan cadangan. Dana yang dihimpun akan dipergunakan untuk meningkatkan permodalan yang nantinya akan disalurkan kepada anggota dalam bentuk kredit. Kredit tersebut pada umumnya dipergunakan oleh anggota untuk modal kerja atau konsumsi.

Melalui kegiatan ini Koperasi Keluarga Tridinanti Palembang memperoleh SHU (Sisa Hasil Usaha) yang dibagikan kepada para anggotanya setiap akhir tahun. Berdasarkan laporan keuangan yang telah ada, pada tahun 2015 sampai 2020 terjadi peningkatan pada aktiva lancar, aktiva tetap, kewajiban lancar, kewajiban jangka panjang dan modal sendiri namun masih berfluktuasi pada SHU. Maka dalam tulisan ini akan dilihat kinerja keuangan Koperasi Keluarga Tridinanti Palembang dari tahun 2015 sampai 2020 berdasarkan analisis rasio likuiditas, rasio solvabilitas dan rasio rentabilitas.

\section{METODOLOGI}

\section{Rancangan Penelitian}

Penelitian yang dilakukan adalah penelitian deskriptif. Penelitian ini akan membahas bagaimana Kinerja keuangan Koperasi Keluarga Tridinanti Palembang dari tahun 2015 sampai 2020 berdasarkan analisis rasio likuiditas, rasio solvabilitas dan rasio rentabilitas.

\section{Operasionalisasi Variabel}

Variabel penelitian ini adalah variabel Kinerja keuangan Koperasi Keluarga Tridinanti Palembang. Koperasi berasal dari bahasa latin cooperere yang dalam Inggris menjadi couperation berarti "bekerja bersama", co berarti bersama dan operation berarti "bekerja" atau "berusaha" (to operate).

Koperasi adalah sebuah perusahaan dimana orang-orang berkumpul bukan untuk menyatukan uang atau modal melainkan sebagai akibat kesamaan kebutuhan ekonomi. Berdasarkan Undang- Undang nomor 12 tahun 1967, koperasi Indonesia adalah organisasi ekonomi rakyat yang berwatak sosial dan beranggotakan orang-orang atau, badan-badan hukum koperasi yang merupakan tata susunan ekonomi sebagai usaha bersama berdasar atas asas kekeluargaan.

Laporan keuangan Koperasi Keluarga Tridinanti Palembang. Laporan keuangan yang dilihat adalah neraca dan laporan rugi laba Koperasi Keluarga Tridinanti Palembang dari tahun 2015 sampai 2020. Laporan keuangan yang akan diteliti adalah Likuiditas, 
Solvabilitas, dan Rentabilitas. Likuiditas adalah kemampuan Koperasi Keluarga Tridinanti Palembang untuk memenuhi kewajiban jangka pendek dengan menggunakan dana lancar yang tersedia pada saat tertentu. Solvabilitas adalah kemampuan Koperasi Keluarga Tridinanti Palembang untuk memenuhi kewajiban jangka panjang. Rentabilitas adalah kemampuan Koperasi Keluarga Tridinanti Palembang untuk menghasilkan keuntungan berupa SHU.

\section{Teknik Analisis}

Data Penelitian ini dilakukan untuk menganalisis kinerja keuangan Koperasi Keluarga Tridinanti Palembang Adapun teknik analisis yang akan dilakukan dalam penelitian ini adalah Data laporan keuangan Koperasi Keluarga Tridinanti Palembang yang terdiri dari neraca dan perhitungan hasil usaha tahun 2015 sampai tahun 2020.

Data itu digunakan untuk mengukur, mengetahui, menggambarkan, menentukan serta membandingkan proporsi pada pos-pos dalam laporan neraca, laba rugi dan arus kas. Analisis rasio merupakan metode analisis yang digunakan dengan menganalisis laporan keuangan pada tahun (periode) tertentu, yaitu dengan membandingkan antara pos yang satu dengan pos lainnya dalam laporan keuangan yang sama dengan tahun yang sama.

Dalam menganalisis rasio keuangan, sebagai standar dalam menilai kinerja keuangan pada penelitian ini digunakan standar yang telah ditetapkan berdasarkan Keputusan Menteri Negara Koperasi dan UKM No.06/Per/M/KUKM/V/2006 tentang Standar Penilaian Kesehatan Keuangan Koperasi. Ada tiga kelompok rasio yang dihitung dalam penelitian ini, yaitu likuiditas, solvabilitas, dan profitabilitas yang dihitung dari data laporan neraca dan rugi laba, kemudian ditabulasi berdasarkan masing-masing rasio dan tahun tanpa uji statistik.
Adapun cara menilai kinerja keuangan koperasi dengan cara perhitungan dari rasio yang terbagi dari tiga kelompok rasio sebagai berikut:

1. Rasio likuiditas, yang akan dihitung dalam rasio ini adalah Rasio lancar (current ratio).

Rasio lancar $=\quad \begin{aligned} & \text { Aktiva Lancar } \\ & \text { Hutang Lancar }\end{aligned}$

Kriteria rasio lancar yang digunakan adalah:

Sangat baik $=200 \%-250 \%$

Baik $\quad=175 \%-<200 \%$

Cukup baik $=150 \%-<175 \%$

Kurang baik $=125 \%-<150$

Buruk $=125 \%$

2. Rasio solvabilitas (Total Debt to Total Assets Ratio), dihitung dengan cara:

Rasio Solvabilitas $=\frac{\text { Total Hutang }}{\text { Total Aktiva }} \quad$ x $100 \%$

Kriteria solvabilitas yang digunakan yaitu Sangat baik $=<40 \%$

Baik $\quad=40 \%-<50 \%$

Cukup baik $=50 \%-<60 \%$

Kurang baik $=60-<80 \%$

Buruk >80\%

3. Rasio rentabilitas atau tingkat pengembalian ekuitas (return on equity-ROE).

$\mathrm{ROE}=\frac{\text { Sisa Hasil Usaha }}{\text { Modal Sendiri }} \quad \mathrm{x} 100 \%$

Kriteria ROE yang digunakan yaitu:

Sangat baik $=21 \%$

Baik $\quad=15 \%-<21 \%$

Cukup baik $\quad=10 \%-<15 \%$

Kurang baik $=3 \%-<10 \%$

Buruk <3\%

\section{HASIL PENELITIAN DAN PEMBAHASAN \\ 1. Kondisi Modal Koperasi Keluarga Tridinanti}


Modal merupakan hal yang penting dalam setiap usaha koperasi. Koperasi tidak dapat berjalan sebagaimana mestinya kalau tidak ada modal. Modal Koperasi Keluarga Tridinanti terdiri atas modal anggota koperasi sendiri. Modal anggota sendiri dapat dikatakan

modal internal karena modal berasal dari bagian sisa hasil usaha yang tidak dibagikan kepada anggota dimasukkan sebagai modal cadangan.

Sifat dari modal ini adalah tertanam dalam waktu yang tidak terbatas. Modal Sendiri Koperasi Keluarga Tridinanti terdiri atas simpanan pokok, simpanan wajib, dana cadangan, dan sisa hasil usaha. Kekayaan koperasi yang sebagian besar berasal dari modal sendiri jauh lebih baik bagi kesinanbungan koperasi. Hal ini tidak hanya akan memberi nilai likuiditas yang tinggi bagi koperasi juga dapat memberikan kepercayaan jaminan kepada kreditur untuk menanamkan modalnya di koperasi.

Perkembangan aset Koperasi Keluarga Tridinanti dapat dilihat pada Tabel 1 di bawah ini.

\section{HASIL PENELITIAN DAN PEMBAHASAN}

\section{Kondisi Modal Koperasi Keluarga Tridinanti}

Modal merupakan hal yang penting dalam setiap usaha koperasi. Koperasi tidak dapat berjalan sebagaimana mestinya kalau tidak ada modal. Modal Koperasi Keluarga Tridinanti terdiri atas modal anggota koperasi sendiri. Modal anggota sendiri dapat dikatakan

modal internal karena modal berasal dari bagian sisa hasil usaha yang tidak dibagikan kepada anggota dimasukkan sebagai modal cadangan.

Sifat dari modal ini adalah tertanam dalam waktu yang tidak terbatas. Modal Sendiri Koperasi
Keluarga Tridinanti terdiri atas simpanan pokok, simpanan wajib, dana cadangan, dan sisa hasil usaha. Kekayaan koperasi yang sebagian besar berasal dari modal sendiri jauh lebih baik bagi kesinanbungan koperasi. Hal ini tidak hanya akan memberi nilai likuiditas yang tinggi bagi koperasi juga dapat memberikan kepercayaan jaminan kepada kreditur untuk menanamkan modalnya di koperasi.

Perkembangan aset Koperasi Keluarga Tridinanti dapat dilihat pada Tabel 1 di bawah ini.

Tabel 1. 1

Perkembangan aset Koperasi Keluarga Tridinanti Modal Sendiri

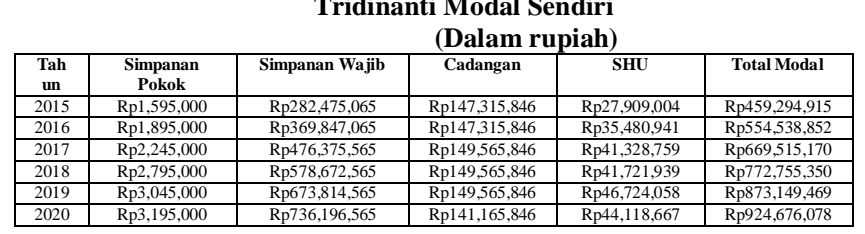

Sumber: Koperasi Keluarga Tridinanti Tahun 2015 - 2020

Berdasarkan Tabel 1 di atas, tampak bahwa modal sendiri Koperasi Keluarga Tridinanti selama lima tahun terakhir yaitu 2015 sampai tahun 2020 mengalami peningkatan. Total modal sendiri tertinggi terjadi pada tahun 2020, hal ini dapat terjadi karena adanya peningkatan jumlah anggota Koperasi Keluarga Tridinanti sehingga menyebabkan terjadinya peningkatan simpanan pokok dan simpanan wajib.

2. SHU merupakan sisa hasil usaha dari sebuah koperasi yang akan dibagikan kepada anggota Koperasi Keluarga Tridinanti berdasarkan atas jasa dari masing-masing anggotanya. Secara umum para anggota Koperasi dapat melihat perkembangan koperasi melalui besarnya SHU yang diperoleh setiap tahun. Sebagian besar anggota menganggap bahwa semakin besar SHU yang diperoleh, maka pengurus koperasi telah menjalankan kegiatannya dengan baik. Perkembangan SHU yang diperoleh 
Koperasi Keluarga Tridinanti dapat dilihat pada Tabel 2 di bawah ini.

Tabel 2. Perkembangan SHU Koperasi Keluarga Tridinanti dari Tahun $2015-2020$

\begin{tabular}{|c|c|c|}
\hline Tahun & $\begin{array}{c}\text { Current } \\
\text { Ratio }\end{array}$ & Kriteria \\
\hline 2015 & $999 \%$ & Sangat Baik \\
\hline 2016 & $1057 \%$ & Sangat Baik \\
\hline 2017 & $1244 \%$ & Sangat Baik \\
\hline 2018 & $1320 \%$ & Sangat Baik \\
\hline 2019 & $1399 \%$ & Sangat Baik \\
\hline 2020 & $1357 \%$ & Sangat Baik \\
\hline
\end{tabular}

Sumber: Koperasi Keluarga Tridinanti Tahun 2015 - 2020

\section{Analisis Rasio Keuangan Koperasi Keluarga Tridinanti}

Kinerja keuangan Koperasi

Keluarga Tridinanti dianalisis dengan mengambil data dari laporan keuangan (neraca dan laporan rugi-laba) selama lima tahun terakhir, yaitu tahun 2015 sampai tahun 2020. Data dianalisis berdasarkan rasio-rasio keuangan, yaitu: rasio likuiditas, rasio solvabilitas, dan rasio rentabilitas.

Dalam penilaian Koperasi Keluarga Tridinanti digunakan pedoman Klasifikasi koperasi yang dibuat oleh Kementrian Koperasi dan Usaha Kecil dan Menengah Republik Indonesia No.06/Per/M/ KUKM/V/2006.

\subsection{Rasio likuiditas}

Rasio Likuiditas menunjukan kemampuan Koperasi Keluarga Tridinanti dalam memenuhi kewajiban jangka pendek tepat pada waktunya. Hasil analisis rasio likuiditas ditunjukan oleh besar kecilnya aktiva lancar, yaitu aktiva yang mudah untuk diubah menjadi kas. Rasio yang tinggi berarti ada kelebihan dana kas atau aktiva lancar lainnya yang akan mempengaruhi profitabilitas dan rasio yang rendah berarti semakin kecilnya jaminan atas kewajiban jangka pendeknya.

Berdasarkan perhitungan analisis rasio likuiditas diketahui bahwa rasio likuiditas berubah dari jangka waktu lima tahun, yaitu tahun 2015 sampai dengan tahun 2020. Nilai Current Ratio berkisar 999\% hingga $1357 \%$. Hasil perhitungan rasio dapat dilihat pada Tabel 3 berikut ini:

Tabel 3. Perhitungan Analisis Rasio Keuangan Likuiditas Koperasi Keluarga Tridinanti tahun 2015 sampai 2020

\begin{tabular}{|c|c|}
\hline Tahun & SHU \\
\hline 2015 & Rp1,595,000 \\
\hline 2016 & Rp1,895,000 \\
\hline 2017 & Rp2,245,000 \\
\hline 2018 & Rp2,795,000 \\
\hline 2019 & Rp3,045,000 \\
\hline 2020 & Rp3,195,000 \\
\hline
\end{tabular}

Pada Tabel 3, dapat dilihat bahwa current ratio tertinggi ada pada tahun 2019, yakni sebesar 1399\% atau sebesar 13,99 kali dibulatkan menjadi 14 kali. Hal ini dapat diartikan dimana Koperasi Keluarga Tridinanti memiliki aset lancar 14 kali lebih banyak dari yang dibutuhkan untuk menutupi hutang lancar yang dimiliki.

Pada Koperasi Keluarga Tridinanti perkembangannya semakin meningkat di tiap tahunnya, kecuali di tahun 2020, keadaan menunjukan penurunan dibanding tahun 2019 hal tersebut disebabkan karena Koperasi Keluarga Tridinanti melakukan penambahan pada pos hutang lancarnya di tahun 2020. Berdasarkan angka-angka ini dapat dilihat upaya dari pihak manajeman untuk mengurangi hutang lancarnya untuk mempertahankan current rationya tetap baik

\subsection{Rasio Solvabilitas}

Rasio Solvabilitas menunjukan kapasitas Koperasi Keluarga Tridinanti untuk memenuhi kewajiban jangka pendek maupun jangka panjang. Rasio ini menyangkut jaminan, yang mengukur seberapa jauh Koperasi Keluarga Tridinanti dibiayai pihak luar (kreditur). Rasio ini juga menunjukan proporsi atas penggunaan investasi untuk membayar hutangnya. Semakin tinggi rasio ini maka 
semakin besar resiko yang dihadapi dan investor akan meminta tingkat keuntungan yang semakin tinggi.

Hasil perhitungan analisis rasio solvabilitas bahwa Koperasi Keluarga Tridinanti berfluktuasi dalam jangka lima tahun, yaitu tahun 2015 sampai tahun 2020. Nilai Total Debt to Total Asset Ratio berkisar antara $7 \%$ sampai dengan $11 \%$. Nilai rasio solvabilitas dapat dilihat pada Tabel 4 berikut ini.

Tabel 4. Perhitungan Analisis Rasio Keuangan Solvabilitas Koperasi Keluarga Tridinanti tahun 2015 sampai 2020

\begin{tabular}{|c|c|c|}
\hline Tahun & $\begin{array}{c}\text { Total Debt } \\
\text { to Total } \\
\text { Asset Ratio }\end{array}$ & Kinerja \\
\hline 2015 & $11 \%$ & Sangat Baik \\
\hline 2016 & $9 \%$ & Sangat Baik \\
\hline 2017 & $7 \%$ & Sangat Baik \\
\hline 2018 & $7 \%$ & Sangat Baik \\
\hline 2019 & $7 \%$ & Sangat Baik \\
\hline 2020 & $7 \%$ & Sangat Baik \\
\hline
\end{tabular}

Sumber: data diolah

Pada Tabel 4 menunjukkan terjadi fluktuasi ratio tertinggi terjadi pada tahun 2015 yaitu sebesar $11 \%$, kemudian menurun pada tahun 2017 hingga 2020 yaitu sebesar $7 \%$. Hal ini dapat diinterpretasikan bahwa total utang yang dimiliki oleh Koperasi Keluarga Tridinanti adalah sebesar 0,07 kali dibanding ekuitas perusahaan, atau $7 \%$ lebih besar dari total ekuitas. Dengan kata lain, setaip Rp 1 (satu rupiah) dari ekuitas Koperasi Keluarga Tridinanti akan menjamin Rp 0,07 rupiah utang atau dengan kata lain. Koperasi Keluarga Tridinanti mampu mengatasi persoalan total utangnya. Walaupun mengalami kenaikan pada total hutang dalam range tahun 2015-2020, namun hal tersebut dapat diimbangi dengan adanya peningkatan pada total aktiva.

\subsection{Rasio Rentabilitas}

Rasio Rentabilitas ini mengukur seberapa besar kemampuan Koperasi Keluarga Tridinanti dalam memperoleh laba dalam hubungannya pendapatan, asset, maupun laba bagi modal sendiri. Rasio ini digunakan untuk mengukur hasil akhir dari sejumlah kebijaksanaan dan keputusan-keputusan yang dibuat oleh tim manajemen Koperasi Keluarga Tridinanti. Efektifitas manajemen meliputi kegiatan fungsional manajemen seperti keuangan,pemasaran, sumberdaya manusia dan operasional.

Analisa rasio rentabilitas dapat memberikan gambaran kemampuan manajemen Koperasi Keluarga Tridinanti dalam memperoleh keuntungan. Perhitungan analisa rasio rentabilitas ini menunjukkan bahwa rasio rentabilitas berfluktuatif dalam jangka waktu enam tahun, yaitu tahun 2015 sampai dengan tahun 2020. Nilai return of equity berkisar antara 5\% hingga $6 \%$.

Hasil perhitungan analisis ini dapat dilihat pada Tabel 5 berikut ini.

Tabel 5. Perhitungan Analisis Rasio Keuangan Rentabilitas Koperasi Keluarga Tridinanti Tahun 2015 sampai 2020

\begin{tabular}{|c|c|c|}
\hline Tahun & $\begin{array}{c}\text { Return of } \\
\text { Equity }\end{array}$ & Kriteria \\
\hline 2015 & $19 \%$ & Baik \\
\hline 2016 & $24 \%$ & Sangat Baik \\
\hline 2017 & $28 \%$ & Sangat Baik \\
\hline 2018 & $28 \%$ & Sangat Baik \\
\hline 2019 & $31 \%$ & Sangat Baik \\
\hline 2020 & $31 \%$ & Sangat Baik \\
\hline
\end{tabular}

Sumber: data diolah

Koperasi Keluarga Tridinanti berdasarkan tabel 4 memiliki Return of Equity berada di range 19\%-31\%, secara spesifik nilai ROE dari tahun 2015 hingga 2020 mengalami kenaikan. Nilai ROE dari tahun 2015-2020 yang berkisar antara $19 \%$ hingga $31 \%$ mengindikasikan tingkat pengembalian ekuitas Koperasi Keluarga Tridinanti dapat dikatakan sangat baik. Nilai Return of Equity yang terjadi pada tahun 2020 terjadi karena dipengaruh oleh Sisa Hasil Usaha yang cukup besar jika dibandingkan tahuntahun sebelumnya. 


\section{KESIMPULAN DAN SARAN 1. Kesimpulan}

Berdasarkan pembahasan hasil penelitian yang telah dikemukakan di bab sebelumnya, dapat disimpulkan bahwa kinerja Koperasi Keluarga Tridinanti selama enam tahun terakhir yaitu tahun 2015 sampai tahun 2020 pada umumnya sudah sangat baik.

Perkembangan rasio likuiditas, solvabilitas dan profitabilitas pada Koperasi Keluarga Tridinanti dari tahun 2015 sampai tahun 2020 adalah sebagai berikut.

a. Kinerja likuiditas Koperasi Keluarga Tridinanti berdasarkan perhitungan rasio likuiditas antara tahun 2015 hingga 2020 yaitu sebesar $999 \%$ hingga 1399\% dikatakan sangat baik (Current Ratio Aset Lancar > 200\% dikatakan sangat baik). Hal ini kemudian menunjukkan bahwa cadangan dan dana jangka pendek sudah berkembang untuk membangun dan mengembangkan koperasi. Nilai tertinggi current ratio terjadi pada tahun 2019 yaitu sebesar $1399 \%$ dan nilai terendah pada tahun 2015 yaitu sebesar $999 \%$.

b. Tingkat Solvabilitas Koperasi Keluarga Tridinanti di tahun 2015 hingga 2020 dalam menjamin hutang dengan modal sendiri adalah $7 \%$ sampai $11 \%$ dapat dikatakan sangat baik (Rasio Solvabilitas DER <40\% dikatakan sangat baik). Rasio tertinggi pada tahun 2015 sebesar $11 \%$ dan terendah ditahun 2017-2020 sebsar $7 \%$.

c. Rentabilitas Koperasi Keluarga Tridinanti pada tahun 2015 hingga 2020 kurang lebih menunjukkan nilai yang sangat baik yaitu berkisar antara $19 \%$ hingga $31 \%$. Nilai retuturn of equity tertinggi terjadi pada tahun 2020 yaitu sebesar $31 \%$ dan terendah di tahun 2015 yaitu sebesar 19\%. Secara garis besarnya dapat dikatakan bahwa rasio-rasio tersebut sudah baik.

\section{Saran}

Berdasarkan simpulan yang telah diuraikan, maka dapat diajukan saran sebagai berikut:

1. Bagi pihak Koperasi Keluarga Tridinanti hendaknya mempertahankan kinerja koperasinya yang sudah baik, dengan mempertimbangkan kebijakan-kebijaka terkait pengelolaan piutang dan persediaan demi meningkatkan kinerja serta pelayanannya kepada anggota, sehingga anggota dapat lebih berpatisipasi dalam kegiatan koperasi.

2. Bagi anggota koperasi untuk dapat meningkatkan partisipasinya dalam kegiatan Koperasi Keluarga Tridinanti agar nantinya dapat meningkatkan perolehan sisa hasil usaha.

Bagi Pemerintah daerah setempat untuk dapat memberikan edukasi dan wawasan kepada masyarakat mengenai keberadaan dan peran serta pentingnya Koperasi Keluarga Tridinanti sehingga dapat meningkatkan partisipasi masyarakat dalam keanggotaan dan berbagai kegiatan yang diseleggarakan oleh Koperasi Keluarga Tridinanti.

\section{DAFTAR PUSTAKA}

Rantau, Ketut, Drs, M.Si, 2016, Analisis Kinerja Keuangan Koperasi Simpan Pinjam Swadaya Di Desa Banyuning Kecamatan Buleleng Kabupaten Buleleng, Fakultas Ekonomi Unversitas Tabanan 
Jurnal Ratri (Riset Akuntansi Tridinanti), Vol. 3, No. 1, hal. 65 - 72, Juli - Desember 2021 p-ISSN 2715 - 0208

$\underline{\text { Buku }}$

Fahmi, Irham. 2012. Analisis Kinerja

Keuangan. Bandung: Alfabeta

Kasmir. (2010). Pengantar Manajemen

Keuangan. Jakarta: Kencana

Prenada Media Group.

Keputusan Menteri Negara Koperasi dan

UKM

No.06/Per/M/KUKM/V/2006.

Tentang "Pedoman Klasifikasi

Koperasi”".

Undang-undang No. 25 Tahun 1992 tentang Perkoperasian (dilengkapi dengan UU No. 12 tahun 1967 tentang Pokok-pokok

Perkoperasian). Jakarta 